\title{
Observatório de neologismos da língua portuguesa: da sala de aula para a pesquisa
}

\author{
Kleber Eckert ${ }^{1}$
}

\begin{abstract}
Resumo
O objetivo deste artigo é apresentar uma síntese dos primeiros resultados de um trabalho de investigação desenvolvido a partir de uma necessidade pedagógica, qual seja, a falta de opções didático-metodológicas nos livros didáticos sobre a formação de novas palavras na língua portuguesa. Trata-se de um estudo nomeado Observatório de Neologismos, cujo desenvolvimento deu-se num projeto de pesquisa executado no IFRS campus Bento Gonçalves, o qual teve, entre seus objetivos, principalmente, identificar a formação de neologismos da língua portuguesa num corpus previamente delimitado; classificar os neologismos nos dois principais subtipos: os de forma e os de sentido; identificar a presença de estrangeirismos; e identificar os processos de formação de palavras presentes nesses neologismos. Para atingir os objetivos propostos, realizouse um estudo teórico acerca do tema dos neologismos e utilizaram-se textos de três colunistas da Revista Época on-line a fim de se identificarem os candidatos a neologismos, o que se nomeou de corpus de extração. De posse das palavras que despertavam um sentimento de novidade, consultou-se o corpus de exclusão, formado por diferentes dicionários gerais da língua, com o intuito de se verificar se as palavras identificadas realmente podiam ser classificadas como unidades neológicas. Por fim, percebeu-se que nas palavras classificadas como neologismos, ocorrem os mesmos processos de formação pelos quais são formadas as palavras já dicionarizadas, tais como a prefixação, a sufixação, a composição, a abreviação e a acrossemia. Os resultados alcançados poderão qualificar o ensino de língua portuguesa no que se refere aos processos de formação de novas palavras.
\end{abstract}

Palavras-chave: Neologismos. Língua Portuguesa. Palavras. Ensino.

\section{Resumen}

El objetivo de este artículo es presentar una síntesis de los primeros resultados de un proyecto de investigación desarrollado a partir de una necesidad pedagógica, es decir, la falta de opciones didáctico-pedagógicas en los libros didácticos sobre la formación de nuevas palabras en portugués. Se trata de un estudio nombrado Observatorio de Neologismos, cuyo desarrollo se dio en un proyecto de investigación llevado a cabo en el IFRS campus Bento Gonçalves, que tuvo, entre los objetivos, principalmente, identificar la formación de neologismos en portugués en un corpus previamente delimitado; clasificar los neologismos en los dos principales subtipos: los de forma y los de sentido; identificar la presencia de extranjerismos; e identificar los procesos de formación de palabras presentes en esos neologismos. Para alcanzar los objetivos propuestos, se hizo un estudio teórico acerca del tema de los neologismos y se utilizaron texto de tres columnistas de la Revista Época on-line para que se identificaran los candidatos a neologismos, lo que se llamó corpus de extracción. Con las palabras que despertaban un sentimiento de novedad en mano, se consultó en corpus de exclusión, formado por distintos diccionarios generales del portugués, para verificar si las palabras clasificadas como neologismos realmente lo eran. Por fin, se notó que, en las palabras clasificadas como neologismos, ocurren los mismos procesos de formación por los cuales se forman las palabras que ya están en los diccionarios, como la prefijación, la sufijación, la composición, la abreviación y la acrosemia. Los resultados logrados podrán calificar la enseñanza de portugués en lo que toca a los procesos de formación de nuevas palabras.

Palabras clave: Neologismos. Lengua Portuguesa. Palabras. Enseñanza.

\footnotetext{
${ }^{1}$ Doutor em Letras e Professor do Instituto Federal de Educação, Ciência e Tecnologia do Rio Grande do Sul IFRS campus Bento Gonçalves.
} 


\section{Introdução}

Este texto apresenta a síntese dos primeiros resultados alcançados no projeto de pesquisa intitulado "Observatório de Neologismos da Língua Portuguesa", desenvolvido no campus Bento Gonçalves, do Instituto Federal de Educação, Ciência e Tecnologia do Rio Grande do Sul - IFRS. O projeto surgiu a partir de uma necessidade percebida no ensino de Língua Portuguesa no 1ㅇ ano do Curso Técnico de Viticultura e Enologia, uma vez que se localizaram poucas opções destinadas às questões de renovação do léxico da língua nos materiais didáticos utilizados nesse nível de ensino.

Dessa forma, o projeto encontra justificativa, e a atividade de pesquisa vincula-se diretamente ao ensino, uma vez que seu surgimento deu-se na aula de língua portuguesa e seus resultados poderão voltar a esse espaço pedagógico. Diante dessas considerações, os objetivos do projeto foram: compreender o conceito de neologismo e suas diferentes acepções;identificar a formação de neologismos da língua portuguesa a partir de um corpus previamente delimitado; classificar os neologismos nos dois principais subtipos: os de forma e os de sentido; identificar, nos neologismos, a presença de estrangeirismos; e identificar, nos neologismos, os processos de formação de palavras.

Para alcançar os objetivos propostos, um percurso metodológico foi seguido. Definiuse o corpus de extração, isto é, os textos que serviram de base para o levantamento dos neologismos. Também foi escolhido o corpus de exclusão, a fim de avaliar se os candidatos a neologismos efetivamente o eram. Trabalhou-se, ainda, com uma ficha neológica, na qual constam vários campos a serem preenchidos. Todo o detalhamento metodológico encontrase descrito no item 2 do presente texto, intitulado "Metodologia para a geração dos dados".

Quanto à organização deste artigo, na primeira parte explicam-se os conceitos de neologia e neologismo, estabelecem-se as relações dos estudos neológicos com as diferentes áreas do conhecimento humano e se discutem o surgimento e a permanência de um neologismo numa determinada língua. Ainda sobre a criação de novas palavras, são apresentadas as áreas mais fecundas, como as gírias e as línguas de especialidade. Nessa primeira parte, detalham-se os neologismos semânticos e os neologismos formais, e mencionam-se os estrangeirismos, embora esse tipo de neologismo não seja o foco do presente artigo.

LínguaTec, Instituto Federal de Educação, Ciência e Tecnologia do Rio Grande do Sul, Bento Gonçalves 
Como já informado anteriormente, na segunda parte deste texto explica-se o percurso metodológico percorrido para que os resultados pudessem ser alcançados. A terceira parte do artigo está dedicada à análise mórfico-semântica dos neologismos selecionados, principalmente com base em Monteiro (2002) e em Alves (2002). Por fim, nas considerações finais, retomam-se os principais pontos destacados na análise dos dados, e se abre a possibilidade para estudos futuros.

\section{Os estudos neológicos}

As pesquisas que abordam os neologismos numa língua situam-se, teoricamente, no campo dos estudos do léxico ou da lexicologia. Logo, à lexicologia cabe o estudo científico do vocabulário, e o léxico de uma língua é compreendido por Correia e Almeida (2012, p. 11) "como o conjunto de todas as palavras que dela fazem parte".

Para Alves (2002, p. 5), o acervo lexical da língua portuguesa, assim como acontece com todas as línguas vivas, renova-se o tempo todo: "enquanto algumas palavras deixam de ser utilizadas e tornam-se arcaicas, uma grande quantidade de unidades léxicas é criada pelos falantes" (ALVES, 2002, p. 05). Concepção semelhante é apresentada por Correia e Almeida (2012, p. 16), ao afirmarem que o léxico costuma ser, assim como o são os demais elementos de uma língua, afetado por mudanças linguísticas, as quais se manifestam em dois níveis: os arcaísmos e os neologismos. Aqueles referem-se a palavras que caem em desuso numa determinada comunidade linguística, e estes referem-se a palavras novas que vão surgindo nessa mesma comunidade.

Os termos neologia e neologismo carregam consigo a acepção de 'novo', percebida no prefixo 'neo', e a ideia de 'noção', vista no radical 'logos', ambos morfemas de origem grega. De acordo com Correia e Almeida (2012, p. 17), à denominação de neologia correspondem dois conceitos distintos, a saber: "a capacidade natural de renovação do léxico de uma língua pela criação e incorporação de unidades novas, os neologismos" e "o estudo (observação, registro, descrição e análise) dos neologismos que vão surgindo na língua" (ALMEIDA; CORREIA, 2012, p. 17). 
Já Carvalho (1987, p. 08) explica que os neologismos estão intimamente ligados às inovações em diferentes áreas da atividade humana, como as artes, a técnica, a ciência, a política e a economia. Além disso, há uma relação de proximidade entre os neologismos e palavras como "mudança, evolução, novidade, novo, criação, surgimento, inovação" (CARVALHO, 1987, p. 08). A autora ainda lembra que a ciência e a tecnologia são as principais fontes de criação e surgimento de neologismos desde o século XX e acrescenta: "além de testemunhar a criatividade e a imaginação fértil de seus falantes, os neologismos têm profunda ligação com as modificações do mundo exterior e as mais diversas áreas de conhecimento" (CARVALHO, 1987, p. 09).

Apoiadas na proposta de Alain Rey (1976), Almeida e Correia (2012, p. 23) definem o neologismo como "uma unidade lexical cuja forma significante ou cuja relação significantesignificado, caracterizada por um funcionamento efetivo num determinado modelo de comunicação, não se tinha realizado no estágio imediatamente anterior do código dessa língua". Dessa definição, segundo as autoras, "decorre que os neologismos podem constituir palavras formalmente novas, palavras preexistentes que adquirirem um novo significado, ou, ainda, palavras que passam a ocorrer em registros linguísticos nos quais não costumavam ocorrer" (ALMEIDA; CORREIA, 2012, p. 24).

De acordo com Almeida e Correia (2012, p. 22), os pesquisadores que têm como objetivo o estudo da neologia precisam adotar critérios objetivos a fim de definir o que considerar um neologismo, uma vez que o simples 'sentimento de novidade' parece ser um critério demasiadamente subjetivo para lidar com a questão. Nesse sentido, no presente trabalho, optou-se pelo critério lexicográfico, isto é, para uma palavra ser considerada neológica, ela não deveria estar registrada nos dicionários mais representativos da língua portuguesa.

Para Correia e Almeida (2012, p. 22-23), além do critério lexicográfico, pode-se considerar a instabilidade formal para a caracterização de um neologismo. Essa instabilidade pode estar ligada à natureza morfológica, fonética ou ortográfica de uma palavra. As autoras exemplificam esse critério com a flutuação de gênero da palavra deadline - como exemplo de natureza morfológica - e a grafia de online, on-line ou on line - como critério ortográfico. 
As mesmas autoras ressaltam que nem todos os neologismos criados numa língua entram, necessariamente, no dicionário. Alguns deles desaparecem tão rapidamente quanto surgiram, pois podem resultar de alguma necessidade comunicativa pontual. Sobre os neologismos que se fixam na língua, ou seja, passam a fazer parte da língua e passam a estar registradas em dicionários, Correia e Almeida (2012, p. 16) esclarecem que isso acontece apenas com aquelas palavras que surgiram por uma necessidade denominativa estável.

A frequência com que um neologismo é repetido

pode determinar a perda do caráter neológico, que vai progressivamente regredindo à medida que seu emprego aumenta. A sua aceitabilidade pelo grupo social determinará sua permanência; caso contrário sua frequência vai diminuindo a cai gradativamente no esquecimento (CARVALHO, 1987, p. 72).

A respeito da permanência de um neologismo numa língua, Alves (2002, p. 84) adota uma perspectiva semelhante a de Carvalho:

Não basta a criação do neologismo para que ele se torne membro integrante do acervo lexical de uma língua. É, na verdade, a comunidade linguística, pelo uso do elemento neológico ou pela sua não-difusão, que decide sobre a integração dessa nova formação ao idioma (ALVES, 2002, p. 84).

Ainda sobre o surgimento e a permanência de um neologismo, Almeida e Correia (2012, p. 25) afirmam que, geralmente, o seu surgimento se dá no nível da fala, e é nesse nível que o neologismo fica situado por um determinado período de tempo. Muitos neologismos, no entanto, nem chegam a entrar no nível da língua, ou seja, desaparecem rapidamente antes de fazerem parte, realmente, do sistema linguístico. Passar do nível da fala para o nível da língua implica o registro do neologismo num dicionário. A partir desse momento, o neologismo deixa de existir enquanto tal, já que está registrado num dicionário.

Sobre a divulgação dos neologismos, Alves (2002, p. 06) acredita que os meios de comunicação de massa e as obras literárias são os principais responsáveis por difundir os neologismos recém criados e, consequentemente, eles passam a ser conhecidos. Na mesma perspectiva, Carvalho (1987) destaca o papel da imprensa no uso e na divulgação de neologismos: "a linguagem da imprensa, apesar de ser a comum, é tratada de maneira funcional, extraindo-se o máximo de poder de penetração e novidade. É aí que entra o neologismo, uma maneira rápida, diferente e, por vezes, mordaz, de transmitir uma notícia" (CARVALHO, 1987, p. 62).

LínguaTec, Instituto Federal de Educação, Ciência e Tecnologia do Rio Grande do Sul, Bento Gonçalves 
Sobre a importância da imprensa no uso e divulgação de neologismos, Alves (2002, p. 08) apresenta os principais resultados de estudos feitos a partir de jornais diários de algumas capitais e de revistas de circulação nacional. Ela também afirma que muitos dos exemplos encontrados na década de 1970 evidenciaram que "certos mecanismos morfossintáticos, não incluídos em gramáticas, já eram vivazes naquele período" (ALVES, 2002, p. 08).

Ainda a respeito de questões gramaticais, Correia e Almeida (2012, p. 13) estabelecem relações entre classes abertas de palavras - tais como substantivos, adjetivos e verbos - e a formação de neologismos, afirmando que as classes abertas

\begin{abstract}
admitem a entrada constante de novas unidades; por isso não é de estranhar que as classes abertas da língua sejam as que apresentam um maior número de unidades (em ordem decrescente: substantivos, adjetivos e verbos) e que sejam também aquelas em que tipicamente ocorrem neologismos, isto é, palavras novas (CORREIA; ALMEIDA, 2012, p. 13).
\end{abstract}

Por outro lado, nas ditas classes fechadas, é mais rara a ocorrência de neologismos, uma vez que "as mudanças nessas classes têm consequências no nível estrutural da língua" (CORREIA; ALMEIDA, 2012, p. 13).

Sobre a criação de palavras, Paviani (2006, p. 82) ilustra o nascimento de neologismos também a partir da fala infantil. Para a pesquisadora, "a criança é uma das maiores inventoras, criadora de palavras novas e ela o faz espontaneamente, levada, talvez, ou por associação de ideias, ou por analogias, ou pela imaginação em si" (PAVIANI, 2006, p. 82). Quando a criança diz, por exemplo, que quer desentrar, "ela encontrou uma forma de dizer, que significa sair, usando uma palavra nova, isto é, que não é de uso comum, talvez por analogia a outras formas com o prefixo des" (PAVIANI, 2006, p. 82).

Outro exemplo fecundo para a criação de novas palavras é o surgimento das gírias, conforme defende Riva (2012, p. 173). Para o autor, “após fazerem parte de um grupo restrito de falantes, como uma forma de manutenção da identidade de tais grupos, são incorporadas à língua geral e podem ser dicionarizadas" (RIVA, 2012, p. 173). O autor cita dois exemplos de expressões idiomáticas que eram, no seu surgimento, circunscritas a grupos específicos, e depois passaram ao uso geral da língua. 'Dar um bafão' era usado apenas por homossexuais e, atualmente, seu uso se expandiu como o significado de 'fazer escândalo'. 'Ser show de bola' se relacionava a um jogo em particular, e hoje seu uso se ampliou, como o significado de 'ser algo extraordinário'.

LínguaTec, Instituto Federal de Educação, Ciência e Tecnologia do Rio Grande do Sul, Bento Gonçalves 
Ainda sobre as gírias, Carvalho (1987, p. 52) nomeia-as de neologismos populares e avalia que elas têm a "capacidade de rapidamente socializar um fato novo ou um sentimento emergente e até de dar uma percepção nova a um sentimento antigo" (CARVALHO, 1987, p. 52). Numa outra perspectiva, Alves $(2002$, p. 65 ) menciona que "nos vocabulários giriáticos, criados com a intenção de dificultar a compreensão por parte daquelas que não integram determinado grupo, a neologia é muito produtiva".

Em relação à neologia de expressões idiomáticas, consoante Riva (2012, p. 175), dificilmente sua origem decorre de alguma palavra importada, como é comum acontecer nos neologismos de uma lexia simples, ou seja, os estrangeirismos não costumam fazer parte do surgimento de um fraseologismo neológico. "Para as lexias complexas podemos observar que as lexias simples que se agrupam para gerar uma expressão já existem em nosso léxico" (RIVA, 2012, p. 175).

Outra fonte profícua de surgimento de neologismos são as línguas de especialidade, as chamadas terminologias (ALVES, 2002, p. 86). Conforme a autora, todos os pesquisadores são categóricos ao afirmarem que a ocorrência de neologismos é mais comum nas línguas de especialidade que na língua geral. A sobreposição daqueles não é fortuita, segundo Alves (2002, p. 87), pois "conceitos técnicos e científicos não cessam de serem criados e têm necessidade de serem nomeados".

Sobre esse tipo de neologismos, Carvalho (1987, p. 34-35) esclarece:

A necessidade de nomeação de objetos novos de forma padronizada advém do fato de que a ciência e a técnica não têm pátria, nem as civilizações são estanques. Há intercâmbio, e qualquer descoberta é logo conhecida no mundo inteiro, sendo designada da maneira que possa ser entendida por falantes de diversas línguas (CARVALHO, 1987, p. 34-35).

De acordo com Correia e Almeida (2012, p. 33), os léxicos das línguas se valem, principalmente, de três mecanismos para a incorporação de novas palavras: "a construção de palavras, recorrendo a regras da própria língua; a atribuição de novos significados a palavras já existentes; a importação de palavras de outras línguas" (CORREIA; ALMEIDA, 2012, p. 33). Além desses mecanismos, podem ser criadas palavras, segundo as autoras, em menor escala, a partir de onomatopeias e da chamada criação ex nihilo, ou seja, do nada. 
Carvalho (1987, p. 22) também menciona alguns processos de criação de novas palavras e afirma que a maioria dos neologismos é formada a partir de morfemas já existentes na língua, o que faz com que se estabeleçam relações entre a palavra nova e conhecimentos linguísticos anteriores. Há no entanto, as criações a partir do nada, conhecidas como ex nihilo, embora elas sejam raras e pouco importantes.

Conforme Alves (2002, p. 05), "um neologismo pode ser formado por mecanismos oriundos da própria língua, os processos autóctones, ou por itens léxicos provenientes de outros sistemas linguísticos", os chamados estrangeirismos. A mesma visão é apresentada por Carvalho (1987, p. 26-26), segundo a qual as novas palavras são construídas utilizando-se diversos tipos de elementos presentes na língua: os prefixos, os sufixos, a redução, a composição, as siglas, a derivação imprópria e os empréstimos de outras línguas.

Correia e Almeida (2012, p. 35) explicam, detalhadamente, como pode ocorrer o processo de construção de palavras dentro do sistema da língua portuguesa:

parte-se de elementos preexistentes (unidades lexicais e infralexicais) e, com base num conjunto de regras interiorizadas e partilhadas pelos falantes, juntam-se esses elementos, de modo a obter novos itens, motivados, de estrutura normalmente transparente, ou seja, itens ou palavras cuja estrutura morfológica é perceptível e cujo significado é coerente com essa estrutura. Também se podem tomar radicais existentes e operar sobre eles transformações diversas. Podem, ainda, tomar-se estruturas pré-construídas (palavras flexionadas, sintagmas, unidades discursivas) e passar a tratá-las como se de palavras se tratasse (CORREIA; ALMEIDA, 2012, p. 35).

Quanto à classificação dos neologismos, pode-se dizer que há uma unanimidade no que se refere aos dois grandes grupos: o neologismo formal e o neologismo semântico (também chamado de conceptual). É o que se percebe na síntese de Carvalho (1987, p. 23): quando uma palavra já dicionarizada é usada com outro significado, trata-se de um neologismo conceptual ou semântico. Por outro lado, quando uma palavra é usada e ainda não está dicionarizada, trata-se, então, de um neologismo formal.

Correia e Almeida (2012, p. 24) apresentam esses dois tipos de neologismos e os nomeiam de novidade formal e novidade semântica: aquela ocorre "quando o neologismo apresenta uma forma não atestada no estágio anterior do registro de língua" e esta "quando o neologismo corresponde a uma nova associação significado-significante, isto é, uma palavra já existente adquire uma nova acepção" (CORREIA; ALMEIDA, 2012, p. 24). 
As autoras argumentam que a novidade formal é construída obedecendo a processos morfológicos ou sintáticos presentes nos processos de formação de palavras da língua, como, por exemplo, a derivação, a composição, as siglas, a lexicalização de sintagmas; além disso, é também observada a partir da importação de palavras de outras línguas, os chamados estrangeirismos. Quanto à novidade semântica, ela ocorre quando uma palavra já conhecida é usada numa acepção que ela não tinha até então, ou seja, ela se torna mais polissêmica (CORREIA; ALMEIDA, 2012, p. 24-25).

Biderman (2001, p. 206) exemplifica como podem surgir os neologismos formais na língua portuguesa:

\begin{abstract}
O neologismo formal constitui uma palavra nova introduzida no idioma. Pode ser um termo vernáculo ou um empréstimo estrangeiro. Por exemplo, biodiversidade, celular, clique [de mouse], scanner, escanear, genoma, genômica (...). Às vezes, o neologismo é uma lexia complexa: coleta seletiva de (do) lixo, endereço eletrônico, paraíso fiscal, ressonância magnética, teoria do caos, transmissão de dados. Ou expressões idiomáticas: acabar em pizza, cair a ficha, sacar um lance, vai rolar uma balada, viajar na maionese. Por vezes as expressões idiomáticas são giriáticas, podendo ou não se incorporar à linguagem geral da comunidade (BIDERMAN, 2001, p. 206).
\end{abstract}

O neologismo semântico ocorre quando não acontece "nenhuma mudança formal em unidades léxicas já existentes" (ALVES, 2002, p. 62), ou seja, quando determinada palavra é usada com um sentido até então não conhecido ou não registrado. A autora acrescenta que certos processos estilísticos, como a metáfora, a metonímia ou a sinédoque, contribuem para a formação de neologismos semânticos ou conceptuais.

Além desses processos, o neologismo semântico também "ocorre quando um termo, característico de um vocabulário, extrapola os limites desse vocabulário e passa a integrar outra terminologia ou a fazer parte da língua geral" (ALVES, 2002, p. 65). A autora cita os exemplos 'corpo-a-corpo' e 'garimpagem', que eram de uso exclusivo do vocabulário esportivo e da exploração de metais e pedras preciosas, respectivamente, e passaram a ser usados com o sentido, na língua geral, de 'discussão difícil e renhida' e 'busca de elementos interessantes e precisos', respectivamente (ALVES, 2002, p. 65).

De acordo com Alves (2002, p. 66), quando um neologismo semântico é difundido e passa a ser aceito e utilizado pelos falantes, é bem provável que o passo seguinte seja a inserção da nova acepção da palavra num dicionário. "Por esse processo, ao significado 
básico de um item léxico vão-se acrescentando os que vierem a ser criados pelo processo da neologia semântica" (ALVES, 2002, p. 66).

Alves (2002, p. 72) explica ainda que o léxico de uma língua não se limita à ampliação de seu acervo a partir de, apenas, processos vernáculos, isto é, o léxico amplia-se também pelo contato dos falantes com outras comunidades linguísticas, através do qual surgem os chamados estrangeirismos. O estrangeirismo, conforme já enunciado anteriormente, é um dos tipos de neologismo formal; no entanto, como o objetivo deste artigo é a análise dos neologismos vernáculos, os estrangeirismos ficarão para um segundo momento.

\section{Metodologia para a geração dos dados}

Quanto à escolha do veículo de comunicação para a identificação de possíveis neologismos, levaram-se em conta as considerações de Almeida e Correia (2012, p. 26), que sugerem os textos veiculados nos meios de comunicação social, tais como jornais e revistas. Essa escolha deu-se porque esses veículos "têm como principal objetivo dar conta do que é novo, notícia" (p. 26), além disso, suas temáticas "são as mais diversificadas possível, sendo maior a probabilidade de encontrar neologismos" (p. 26), sem contar com a facilidade de acesso.

Nesse sentido, para a escolha do corpus de extração, definiu-se a versão on-line da Revista Época por várias razões. A primeira delas é por ser uma revista de circulação nacional e a sua versão on-line ser de fácil acesso e apresentar uma profusão de notícias. Além disso, a escolha também levou em conta o fato de a versão on-line apresentar uma diversidade de colunistas, que semanalmente publicam artigos de opinião sobre os mais diversos temas.

Foram selecionados os textos dos colunistas Jairo Bouer, Marcio Atalla e Bruno Astuto, cujos temas são Saúde, Educação Física e Celebridades, respectivamente. Os textos do corpus de extração foram publicados entre janeiro de 2016 e julho de 2017. Desse corpus, foram selecionados 60 candidatos a neologismos, dos quais 30 foram efetivamente classificados como unidades neológicas, após a consulta ao corpus de exclusão. Desses 30 neologismos, 15 serão objeto de análise neste artigo, uma vez que os demais foram classificados como estrangeirismos, os quais ficarão para uma análise posterior.

LínguaTec, Instituto Federal de Educação, Ciência e Tecnologia do Rio Grande do Sul, Bento Gonçalves v. 3, n. 1, p. 1-19, jun. 2019. 
A fim de avaliar que os candidatos a neologismos realmente o eram, definiu-se o corpus de exclusão, constituído pelos dicionários Aurélio, Houaiss e Aulete Digital, além de se fazerem consultas, de caráter complementar, ao VOLP - Vocabulário Ortográfico da Língua Portuguesa². De acordo com Correia e Almeida (2012, p. 26), é importante definir o corpus de exclusão pois ele serve para "verificar o caráter neológico dos dados recolhidos".

As mesmas autoras asseveram que esse corpus "é constituído por um conjunto de dicionários gerais da língua recentes, que se consideram representativos do estado atual do léxico da língua em causa (CORREIA; ALMEIDA, 2012, p. 26). Portanto, se o corpus de exclusão for constituído por dicionários, o critério para determinar o caráter neológico de uma palavra será o critério lexicográfico, que foi o adotado no presente estudo.

Ainda no campo da metodologia, os textos do corpus de extração foram lidos com muita atenção e, quando se percebia alguma palavra que despertasse no pesquisador um sentimento de novidade, essa palavra era selecionada como candidata a neologismo e registrada numa ficha. A ficha foi adaptada a partir da metodologia sugerida por Eckert et al. (2013), e nela constam os seguintes campos: na coluna da esquerda, está o candidato a neologismo e, na linha imediatamente abaixo, o contexto de ocorrência. Na coluna da direita, a localização desse neologismo, logo abaixo a definição elaborada pelo pesquisador e na sequência as definições nos dicionários pertencentes ao corpus de exclusão. Na parte de baixo da tabela, há um espaço para conclusões, isto é, se o neologismo se confirma ou não e, em caso afirmativo, se se trata de um neologismo formal ou de um neologismo semântico. $A$ seguir, registra-se o modelo adotado na pesquisa que serviu de base para a escrita do presente texto:

\footnotetext{
2 De acordo com Garcez (2001, p. 195), “O Vocabulário Ortográfico da Língua Portuguesa (VOLP) é uma publicação eventual da Academia Brasileira de Letras em que se encontram listados os vocábulos da língua, sendo que os neologismos acrescentados a cada edição passam a ser chancelados como propriamente pertencentes à língua".
}

LínguaTec, Instituto Federal de Educação, Ciência e Tecnologia do Rio Grande do Sul, Bento Gonçalves 


\begin{tabular}{|l|l|}
\hline Candidato a neologismo: & Localização: \\
\hline Contexto de ocorrência: & Definição no contexto: \\
\cline { 2 - 2 } & VOLP: \\
\cline { 2 - 2 } & Houaiss: \\
\cline { 2 - 2 } & Aurélio: \\
\cline { 2 - 2 } & Aulete Digital: \\
\hline Conclusão: & \\
\hline
\end{tabular}

Quadro 01 - Ficha neológica

Fonte: Adaptado de Eckert et al. (2013)

No item a seguir, far-se-á a análise morfológica (e semântica) dos neologismos identificados no projeto, a saber: agênero, antivacinação, superbactéria, minipicareta, trans, telona, viralizada, majoritariamente, população-alvo, sorodiscordantes, webséries, estar ligado, HCG, Hiit e TRX.

\section{Análise dos dados}

Quanto aos neologismos selecionados, destacam-se os formados pelo processo de derivação prefixal, ou seja, quando um prefixo é acrescentado à base, formando-se uma nova palavra. Monteiro (2002, p. 54) lembra que os prefixos são facilmente identificados, uma vez que, quando destacados, resta uma palavra inteira. No caso do corpus em análise, revelaram-se quatro neologismos formados pelo processo da derivação prefixal.

Alves (2002, p. 15) afirma que os prefixos de caráter negativo ou opositivo são os mais fecundos na formação de novos itens léxicos. Entre eles, está a forma a- de agênero. É preciso perceber que a palavra agênero é utilizada como adjetivo do substantivo moda, com o sentido de definir a moda sem gênero. Logo, com o acréscimo do prefixo, houve também a mudança de classe gramatical, pois gênero classifica-se como substantivo. 
(1) "E o que o Renascimento italiano tem a ver coma moda agênero da Gucci? Basta lembrar-se dos homens do século XV que se ofereciam para posar para os artistas da época, uma atitude que, até então, era atribuída às prostitutas fiorentinas" (Bruno Astuto).

Outro prefixo considerado muito fecundo contemporaneamente por Alves (2002, p. 16) é anti-, que "denota valor opositivo 'de contrário a alguma coisa ou alguém'”, conforme exemplo a seguir:

(2) "O falso estudo deu força ao movimento antivacinação, que prega que os responsáveis por crianças não as deixem receber esse tipo de imunização" (Jairo Bouer).

Trata-se de nomear o polêmico movimento que se opõe aos programas de imunização das crianças. Nesse caso, a classe gramatical da palavra base se mantém, o que é considerado por Monteiro (2002, p. 54) como o mais comum de acontecer com a derivação prefixal.

Entre os prefixos que possibilitam a formação de neologismos com o acréscimo da ideia de superioridade, exagero ou grandeza, Alves (2002, p. 19) afirma que o mais comum é o prefixo super-, que pode ser acrescentado a palavras de caráter substantival, adjetival e verbal. No presente corpus, encontra-se a palavra superbactéria, neologismo formado pela junção do prefixo super-e do substantivo bactéria, a fim de destacar uma de suas características principais, ou seja, a dificuldade em ser combatida pelos antibióticos disponíveis na atualidade.

(3) "Com 34 casos já confirmados, o grande temor das autoridades é o surgimento de uma superbactéria que não seja sensível a nenhum dos antibióticos disponíveis hoje" (Jairo Bouer).

O quarto exemplo de neologismo formado por prefixação é o substantivo minipicareta, que se originou do acréscimo do prefixo mini- ao substantivo picareta. De acordo com Alves (2002, p. 20), esse prefixo é usado para a formação de neologismos com o valor de "pequena dimensão" e geralmente é acrescentado a palavras de base substantiva, conforme exemplo a seguir:

(4) "No longa-metragem ele interpreta tio Tony, que vive de pequenos golpes. 'Ele não chega a ser mau-caráter, é um minipicareta adorável', adianta" (Bruno Astuto).

Ainda no campo do uso dos prefixos, embora com um enfoque diferente, encontra-se o neologismo trans, formado unicamente pelo prefixo e utilizado como adjetivo independente a partir da abreviação de transexual.

LínguaTec, Instituto Federal de Educação, Ciência e Tecnologia do Rio Grande do Sul, Bento Gonçalves v. 3, n. 1, p. 1-19, jun. 2019. 
(5) "A atriz interpreta a mãe de Ivana (Carol Duarte), que virará trans" (Bruno Astuto).

A palavra transexual é formada pela junção do prefixo trans- e do adjetivo sexual, e significa aquela pessoa que não se identifica com o próprio sexo, e sim com o sexo oposto. No exemplo acima, nota-se o caráter adjetival do neologismo também pela construção sintática, uma vez que ele é usado como predicativo do sujeito da oração, vindo logo após um verbo de ligação, além de caracterizar o substantivo Ivana.

No corpus selecionado, também há neologismos formados por derivação sufixal, processo que Alves (2002, p. 29) considera bastante produtivo na imprensa contemporânea. Para Monteiro (2002, p. 55), "devem ser analisados como sufixos os elementos significativos que aparecem após a raiz da palavra" e, diferentemente dos prefixos, eles nem sempre podem ser destacados com muita facilidade.

O primeiro neologismo formado por sufixação é telona, cujo sufixo -ona é acrescentado ao substantivo tela com o intuito de destacar o seu tamanho, uma vez que o sufixo é formador de aumentativos. No exemplo citado abaixo, percebe-se uma referência à tela de cinema, que se diferencia das demais telas pelo seu tamanho. É preciso notar que, neste caso, ao contrário do que ocorre com muitos dos sufixos acrescidos a uma palavra base, não ocorre mudança de classe gramatical.

(6) “Para ela, a indústria do tabaco está usando a telona como uma espécie de última fronteira para anúncios, mensagens subliminares e patrocínios, já que uma série de medidas em diversos países passou a restringir a publicidade do tabaco" (Jairo Bouer).

Outro neologismo formado por sufixação é o adjetivo viralizada, oriundo do verbo viralizar, que é, também, uma palavra neológica formada a partir do adjetivo viral. Em relação a esse verbo, Alves (2002, p. 34) ressalta que o sufixo-izar é um dos mais produtivos na formação neológica de verbos. É preciso também perceber o sentimento de novidade intrínseco ao adjetivo viral, que saiu do campo restrito da área da saúde e foi para o da internet e das redes sociais, embora tenha mantido a ideia de algo que se espalha com facilidade; portanto, viralizado é algo que se torna muito comum nas redes sociais, seja uma imagem, um vídeo ou uma frase.

(7) “O primeiro deles foi uma gravação feita de uma mulher que chegava a um restaurante sofisticado em São Paulo, caiu ao descer do carro e foi arrastada pela enxurrada por alguns metros, durante uma forte chuva que acontecia na cidade.Alguém gostaria de ser filmado nessa situação e ver sua imagem viralizada pelas redes sociais?” (Jairo Bouer)

LínguaTec, Instituto Federal de Educação, Ciência e Tecnologia do Rio Grande do Sul, Bento Gonçalves v. 3, n. 1, p. 1-19, jun. 2019. 
O terceiro exemplo de neologismo formado por sufixação é o advérbio majoritariamente. Para Alves (2002, p. 35),-mente é o “único sufixo de caráter adverbial a formar palavras na língua portuguesa, (...) expressa uma intensa produtividade ao juntar-se a bases adjetivas femininas para designar 'modo'". A autora ainda afirma que, por ser um mecanismo muito fértil na formação de advérbios, não há muitos registros de advérbios terminados em -mente nos dicionários.

(8) "É o retrato de uma guerra urbana, que provoca a morte de dezenas de jovens, principalmente garotos, todo dia. As vítimas são majoritariamente pobres, negros e habitantes de periferias" (Jairo Bouer).

No corpus selecionado para análise, foi possível identificar também neologismos formados pelo processo da composição, "que consiste na criação de palavras novas pela combinação de vocábulos já existentes" (KEHDI, 2007, p. 35). O primeiro deles é populaçãoalvo, formado pelos substantivos população e alvo, com o intuito de definir o grupo de pessoas para o qual está dirigido algum objetivo específico. Nesse caso de união de dois substantivos, Kehdi (2007, p. 42) observa que "dois elementos se unem por concordância ou coordenação" e que "o determinante pode preceder o determinado", neste caso, a população que é alvo.

(9) "No ano passado, a cobertura vacinal foi a menor dos últimos três anos. Dados do Ministério da Saúde mostram que 83,8\% da população-alvo foi imunizada em 2015, número inferior à média nacional, de 87,2\%" (Jairo Bouer).

Um segundo caso de neologismo formado por composição é o adjetivo sorodiscordante, cujo significado é atribuído no caso de uma relação entre um portador soropositivo que convive com um soronegativo, isto é, um deles tem o vírus HIV e o outro não. Nesse caso, houve a formação de um novo adjetivo a partir da sequência substantivo + adjetivo e, segundo Alves (2002, p. 45), "as bases que compõem a nova unidade lexical desempenham a mesma função que a do elemento recém-formado e associam-se copulativamente a fim de formarem esse neologismo".

(10) "O uso de medicamentos antirretrovirais tornou praticamente nula a chance de transmissão do HIV entre casais sorodiscordantes (quando um está infectado pelo vírus e o outro não), mesmo quando eles não usam preservativos em suas relações sexuais" (Jairo Bouer). 
O último exemplo de neologismo formado por composição é o substantivo websérie, formado pela junção do anglicismo web ao vernáculo série. A palavra significa um série (espécie de filmes exibidos em episódios) desenvolvida e apresentada exclusivamente para ser veiculada pela internet, e não pela televisão convencional. Trata-se, portanto, de um exemplo de composto neológico híbrido, processo que, segundo Alves (2002, p. 78), começa a se tornar um fenômeno comum na língua portuguesa. Para a autora, "a integração à língua portuguesa manifesta-se nos casos em que o estrangeirismo começa a formar derivados compostos" (ALVES, 2002, p. 78).

(11) "Além disso, a OMS sugere que mensagens com alertas sobre os riscos do cigarro deveriam ser exibidos antes de filmes, séries de TV e webséries que contenham imagens de pessoas fumando" (Jairo Bouer).

Outra construção neológica em língua portuguesa é a composição sintagmática estar ligado, com o significado de estar conectado à internet ou às redes sociais ou ainda ao celular o tempo todo. Trata-se de um sentido novo à expressão estar ligado, que significa também estar atento a algo.

(12) "Além do impacto que a radiação azul, emitida pelas telas dos dispositivos, tem no ciclo do sono, o próprio fator comportamental de estar ligado, sempre disponível, deixa os jovens em um estado de excitação quase incompatível com uma noite de sono reparador" (Jairo Bouer).

Para Alves (2002, p. 50) essa composição sintagmática processa-se "quando os membros integrantes de um segmento frasal encontram-se numa íntima relação sintática, tanto morfológica quando semanticamente, de forma a constituírem uma única unidade léxica". Ainda sobre a formação desse tipo de neologismos, Riva (2012, p. 175) lembra que as lexias simples que formam a lexia complexa, no caso estar ligado, já existem em nosso léxico e que elas apenas se agrupam numa nova formação com um novo sentido.

No corpus analisado, também surgiram três neologismos formados a partir de siglas, processo nomeado por Monteiro (2002) como acrossemia. Essas siglas, no entanto, são originadas da língua inglesa e são, portanto, também classificadas como estrangeirismos. A primeira delas é a sigla de Human Chorionic Gonadotrophin- HCG - que em português é gonadotrofina coriônica humana, que é uma glicoproteína hormonal, produzida pela placenta durante a gestação. 
(13) "Estou terminando uma dieta HCG. Que tipo de alimentação é ideal para ter saúde e manter o peso?" (Marcio Atalla).

A segunda sigla é Hiit, advinda da expressão High-intensity interval trainig e pode ser traduzida como Treino Intervalado de Alta Intensidade. É usada para definir um tipo de treino físico, como pode ser visto no exemplo:

(14) "Não gosto de academia. Para me exercitar, prefiro dançar, mas tenho vergonha de fazer aulas. Estou seguindo aulas de aero Hiit pela internet. Posso fazer todos os dias ou há alguma restrição?" (Marcio Atalla).

A última sigla identificada no corpus é TRX, que provém de Total-body Resistance Exercise ou Exercício de Resistência do Corpo Inteiro. É o nome dado também ao aparelho usado para a execução de treino em suspensão, que é uma espécie de fita com a qual se desenvolvem os exercícios físicos.

(15) "Continue fazendo suas aulas de aeróbica em casa e procure outros estilos de aulas, como a ginástica localizada, funcional, TRX, exercícios com elásticos" (Marcio Atalla).

A respeito dos neologismos formados por siglas, Alves (2002, p. 56) acredita que sua formação dá-se por economia discursiva, já que "o sintagma é reduzido de modo a tornar-se mais simples e mais eficaz no processo de comunicação". A presença de siglas formadas em língua inglesa não ocorre por acaso, já que "o inglês é a grande fonte contemporânea de empréstimos ao português e às demais línguas" (GARCEZ; ZILLES, 2001, p. 22). Ademais, no corpus analisado, foram identificados outros 15 estrangeirismos, todos oriundos da língua inglesa, os quais serão objeto de análise em um texto futuro.

\section{Considerações finais}

Após analisar os neologismos extraídos dos textos publicados pelos colunistas da Revista Época on-line foi possível chegar a algumas conclusões. Em primeiro lugar, percebese que a formação de novas palavras dá-se em praticamente todos os campos do saber, seja na linguagem especializada, seja na linguagem do cotidiano. No presente caso, nos textos das três áreas escolhidas - saúde, educação física e celebridades - em todas elas houve a presença sistemática de unidades neológicas. Registra-se, ainda, que a escolha de um 
veículo de comunicação como corpus de extração não foi fortuita, e sim, motivada por outras pesquisas já realizadas na área dos neologismos.

Em segundo lugar, os neologismos localizados e analisados indicaram diferentes processos de formação de palavras, tais como a prefixação, a sufixação, a abreviação vocabular, a composição e a acrossemia. Em todas elas, há pelo menos um exemplo a ser identificado, o que leva à conclusão de que os neologismos comportam-se, morfologicamente, como quaisquer palavras de uma língua.

Embora não tenha sido o foco de reflexão do presente artigo, a presença de um elevado número de estrangeirismos provenientes da língua inglesa também chama a atenção. Inclusive houve a formação de siglas a partir de expressões em inglês, tais como HCG, Hiit e TRX, todas elas provenientes de textos da área da Educação Física. Como estudo futuro, pretende-se fazer a análise de todos os neologismos originados por estrangeirismos, os quais chegam ao número de 15 de um total de 30 neologismos identificados no corpus de extração.

Finalmente, acredita-se que o objetivo da pesquisa tenha sido plenamente alcançado, uma vez que foi possível identificar os neologismos, classificá-los e analisá-los com base em autores do campo da morfologia e, a partir dela, da neologia. Talvez esta pesquisa abra caminho para outras a serem feitas, talvez até mesmo alguma exploração no campo do léxico especializado ou da terminologia. Ademais, os resultados alcançados e a metodologia utilizada poderão, ainda, ser utilizados em aulas de língua portuguesa na no Ensino Médio/Técnico, e até mesmo na formação e aperfeiçoamento de professores de língua e literatura.

\section{Referências}

ALVES, I. M. Neologismo - criação lexical. 2 ed. São Paulo: Ática, 2002.

BIDERMAN, M. T. C. Teoria linguística: teoria lexical e linguística computacional. 2 ed. São Paulo: Martins Fontes, 2001.

CARVALHO, N. O que é neologismo. 2 ed. São Paulo: Brasiliense, 1987.

CORREIA, M.; ALMEIDA, G. M. de B. Neologia em português. São Paulo: Parábola, 2012.

Dicionário Aulete Digital. Disponível em: http://www.aulete.com.br/ Acesso em: 03 de jan. de 2018. 
ECKERT et al. Observatório de neologismos da Língua Portuguesa: relações entre ensino e pesquisa. In: Revista Philologus, ano 19, n. 57, set./dez. 2013. Rio de Janeiro: CiFEFil.

FERREIRA, A. B. de H.; FERREIRA, M. B. (Coord.) Dicionário Aurélio da língua portuguesa. 8 ed. Curitiba: Positivo, 2012.

GARCEZ, P. M.; ZILLES, A. M. S. Estrangeirismos - desejos e ameaças. In: FARACO, C. A. (Org.). Estrangeirismos: guerra em torno da língua. São Paulo: Parábola Editorial, 2001.

GARCEZ, P. M. A proposta de legislação antiestrangeirismos no Congresso Nacional do Brasil (1999-2003). In: FARACO, C. A. (Org.). Estrangeirismos: guerra em torno da língua. São Paulo: Parábola Editorial, 2001.

HOUAISS, A.; VILLAR, M. de S.; FRANCO, F. M. de M. Dicionário Houaiss da língua portuguesa. Rio de Janeiro: Objetiva, 2009.

KEHDI, V. Formação de palavras em português. 4 ed. São Paulo: Ática, 2007.

MONTEIRO, J. L. Morfologia Portuguesa. 4 ed. Campinas: Pontes, 2002

PAVIANI, N. M. S. Linguagem e práticas culturais. Caxias do Sul: Educs, 2006.

Revista Época on-line. Disponível em: https://epoca.globo.com/ Acesso em: 18 de dez. de 2017.

RIVA, H. C.A neologia fraseológica na língua portuguesa do Brasil. In: SILVA, S. (Org.). Fraseologia e Cia: entabulando diálogos reflexivos. Londrina: UEL, 2012.

Vocabulário Ortográfico da Língua Portuguesa - VOLP. Disponível em: http://www.academia.org.br/nossa-lingua/busca-no-vocabulario Acesso em: 03 de jan. de 2018.

Data de submissão: 25/02/2019. Data de aprovação: 14/05/2019. 